\title{
Global Impact of Corrosion: Occurrence, Cost and Mitigation
}

\author{
Mohammad A Jafar Mazumder* \\ Chemistry Department, King Fahd University of Petroleum \& Minerals, Saudi Arabia
}

*Corresponding author: Mohammad A Jafar Mazumder, Chemistry Department, King Fahd University of Petroleum \& Minerals, Dhahran 31261, Saudi Arabia.

Received Date: May 23, 2020

Published Date: June 02, 2020

\begin{abstract}
In atmospheric conditions, most of the metals and alloys are unstable and prone to corrosion. The corrosion potentially affects industrial equipment, reduce the shelf life of the infrastructure assets and the quality of the environment. Therefore, it is essential to control the corrosion to save considerable expenses in materials, equipment, and structure. This review article provides a brief overview and impact of corrosion, recent incidence related to corrosion, incurred cost, and mitigation methods of corrosion.
\end{abstract}

Keywords: Corrosion; Effect of corrosion; Corrosion-related incidence; Corrosion cost; Mitigation

\section{Concepts of Corrosion}

According to ISO 8044 standard, corrosion can be defined as the deterioration of the metals by the physicochemical interaction between metals and its environment or technical system, of which these form a part [1]. From a realistic point of view, corrosion can be observed as "the chemical reversion of refined metal to its most stable energy state" [2]. Theoretically, corrosion is considered a confined electrochemical oxidation and reduction reaction that takes place on the metal surface. The electrochemical corrosion process consists of an anode, cathode, and aqueous solution, or electrolyte having positively and negatively charged ions that possess some conductivity. Typically, upon dissolution of metals, the electrons have been transferred to another position on the surface that results in gradual deterioration and consequent failure of the host metal.

Corrosions are of many kinds, but they can be subdivided into two main types, internal and external. External corrosion is

Table 1: Different corrosive environments. regarded as the corrosive effect of high temperature, high humidity, high salt, and highly acidic environments on the metallic part of the alloy [3]. On the contrary, internal corrosion is associated with stored or transported gases or liquids [4]. Continuous exposure of the metal to fluids can cause this type of corrosion either in anaerobic or aerobic conditions [5]. Water is believed to be the most common liquid that has contact with extremely corroded metallic planes. At the same time, oil, despite being not corrosive, contains hydrocarbon phases, most of which are complex emulsions containing oxygen, water, and other dissolved corrosive gases.

The petroleum production operations suffer from different types of corrosion involving several mechanisms. The four broad groups of electrochemical, chemical, biological, and mechanically assisted corrosions are presented in Table 1, and briefly discuss their cause and affected areas to shed some light on the effects of corrosion on oil and gas production in petrochemical industries (Table 1).

\begin{tabular}{|c|c|c|c|}
\hline Nature of Corrosion & Type of Corrosion & Cause of Corrosion & Affected Areas/Materials \\
\hline \multirow{4}{*}{$\begin{array}{c}\text { Electrochemical } \\
\text { corrosion }\end{array}$} & Galvanic corrosion & Difference in electrode potentials. & Metal with more negative potential. \\
\cline { 2 - 4 } & Crevice corrosion & Metal within narrow clearances being devoid of oxygen. & Crevices. \\
\cline { 2 - 4 } & Pitting corrosion & Chloride ions. & Passive metals. \\
\cline { 2 - 4 } & Stray current corrosion & Extraneous DC from electrified mining operations. & Underground pipelines. \\
\hline
\end{tabular}




\begin{tabular}{|c|c|c|c|}
\hline \multirow{5}{*}{ Chemical corrosion } & Oxygen corrosion & Depolarization and electron acceptance capability of $\mathrm{O}_{2}$. & Drill pipes. \\
\hline & Sour corrosion & $\mathrm{H}_{2} \mathrm{~S}$ working as an acid in $\mathrm{H}_{2} \mathrm{O}$. & Deep wells. \\
\hline & Sweet corrosion & $\mathrm{CO}_{2}$ producing $\mathrm{H}_{2} \mathrm{CO}_{3}$ in $\mathrm{H}_{2} \mathrm{O}$. & $\begin{array}{l}\text { Transmission pipelines, main down- } \\
\text { hole tubing. }\end{array}$ \\
\hline & $\begin{array}{l}\text { Concentrated brines } \\
\text { corrosion }\end{array}$ & Dense halide brines of $\mathrm{Ca}, \mathrm{Zn}$ and $\mathrm{Mg}$. & Stainless steels. \\
\hline & Strong acids corrosion & $\mathrm{HCl}, \mathrm{HF}$, etc., pumped into the wells to increase permeability. & Deep wells. \\
\hline Biological corrosion & $\begin{array}{l}\text { Microbiologically In- } \\
\text { duced corrosion }\end{array}$ & Organic acids, $\mathrm{CO}_{2}, \mathrm{H}_{2} \mathrm{~S}$ produced by fungi and bacteria. & Underground pipelines. \\
\hline \multirow{7}{*}{$\begin{array}{l}\text { Mechanically assisted } \\
\text { corrosion }\end{array}$} & Cavitation & Gas bubbles' implosion on metal surfaces. & $\begin{array}{l}\text { High-speed blade propellers and } \\
\text { pumps. }\end{array}$ \\
\hline & Erosion & Cutting action of high-velocity abrasive particles. & Drill pipes. \\
\hline & Erosion corrosion & $\begin{array}{l}\text { Removal of a protective film of corrosion products by } \\
\text { erosion. }\end{array}$ & Propellers, impellers, pumps, valves. \\
\hline & Corrosion fatigue & Alternating stresses in a corrosive environment. & $\begin{array}{l}\text { Drill ships, drilling and production } \\
\text { rigs, and platforms. }\end{array}$ \\
\hline & Sulfide stress corrosion & Dispersion of molecular $\mathrm{H}_{2}$ into the metals' matrices. & $\begin{array}{l}\text { Valve trim, preventer hard parts } \\
\text { and tool joints. }\end{array}$ \\
\hline & Chloride stress cracking & $\begin{array}{l}\text { Tensile stress in the presence of } \mathrm{O}_{2} \text {, } \mathrm{Cl} \text { - and high tempera- } \\
\text { ture. }\end{array}$ & $\begin{array}{l}\text { Stainless steels, pipe-wells, and } \\
\text { tubing bundles. }\end{array}$ \\
\hline & $\begin{array}{l}\text { Stress corrosion crack- } \\
\text { ing }\end{array}$ & Corrosive environment and non-cyclic tensile stress. & $\begin{array}{l}\text { Bridge cables, landing gear on } \\
\text { aircraft. }\end{array}$ \\
\hline
\end{tabular}

\section{Effects of Corrosion}

The effects of corrosion shade our daily life both by direct and indirect means. It is straightforward in the sense that corrosion has an impact on the useful service lives of our possessions, and indirect, in which producers and suppliers of goods and services incur corrosion costs, which they pass onto the consumers. At home, corrosion can easily be recognized on metal tools, automobile body panels, charcoal grills, and outdoor furniture. Painting is one of the significant preventative maintenances that safeguards such items from corrosion. Corrosion protection is built into all major household appliances such as furnaces, dryers, washers, ranges, and water heaters [6].

How corrosion affects us from home to work is of much more severe consequence. The corrosion of steel reinforcing bars in concrete can occur without being noticed. It can cause the failure of a section of highway, damage to buildings, bridges, parking structures, and the collapse of electrical towers, etc., resulting in significant economic loss and jeopardizing public safety. Corrosion that occurs in major industrial plants, such as chemical processing plants or electrical power plants, is perhaps the most dangerous of all. Such type of corrosion could result in plant shutdowns. Some corrosion consequences are economical and result in the following:

- Replacing the corroded equipment

- $\quad$ Taking preventive measures, such as painting

- $\quad$ Equipment shut down due to corrosion failure
- Overdesigning to allow for corrosion

- $\quad$ Efficiency loss

- Damage of equipment adjacent to one in which corrosion failure occurs.

Some consequences are social and can cause the following issues:

- Health, for instance, an escaping product from corroded equipment or corrosion product itself can cause pollution

- Safety, as an example, sudden failure can cause an explosion, fire, release of a toxic product, and/or construction collapse

- Unpleasant appearance of the corroded materials to the eye

- Depletion of natural resources, including the metals and fuels used to manufacture them.

\section{Corrosion Related Accidents}

The circumstances can much exaggerate corrosion damage. Throughout history, many corrosion accidents have gone unnoticed for reasons of liability or simply because the evidence disappeared in the catastrophic event; others have made the headlines. Some devastative corrosion accidents that have claimed lives and incurred substantial economic losses are included in Table 2. 
Table 2: List of some renowned corrosion accidents.

\begin{tabular}{|c|c|c|c|}
\hline Name of Accidents & Year & Place & Reason and Damage \\
\hline Silver Bridge Collapse & 1967 & Ohio, USA & $\begin{array}{c}\text { The U.S. highway } 35 \text { bridge in between Point Pleasant, West Virginia and Kanauga, Ohio, fall down } \\
\text { into the Ohio river. Stress corrosion cracking and corrosion fatigue was responsible for this col- } \\
\text { lapse. This accident claimed } 46 \text { lives. }\end{array}$ \\
\hline Bhopal Accident & 1984 & $\begin{array}{l}\text { Bhopal, } \\
\text { India }\end{array}$ & $\begin{array}{l}\text { Methylisocyanate (MIC) storage tank leaked due to corroded pipelines, valves, and other safety } \\
\text { equipment at Union Carbide India Ltd caused the release of MIC and other chemicals into the sur- } \\
\text { rounding area. This incidence claims } 3000 \text { people killed, and 500,000 people were injured. }\end{array}$ \\
\hline $\begin{array}{l}\text { Swimming Pool Roof } \\
\text { Collapse }\end{array}$ & 1985 & $\begin{array}{l}\text { Uster, } \\
\text { Switzer- } \\
\text { land }\end{array}$ & $\begin{array}{l}\text { After } 13 \text { years of use, the concrete roof supported by stainless steel collapsed due to stress corro- } \\
\text { sion cracking. This claim } 12 \text { people killed. }\end{array}$ \\
\hline The Aloha Incident & 1988 & $\begin{array}{l}\text { Island } \\
\text { of Maui, } \\
\text { Hawaii }\end{array}$ & $\begin{array}{l}\text { A 19-year-old Boeing } 737 \text { lost a significant portion of the upper fuselage in operating flight due to } \\
\text { multiple corrosion fatigue damage. 1-flight attendant lost her life. }\end{array}$ \\
\hline $\begin{array}{l}\text { Guadalajara Sewer Ex- } \\
\text { plosion }\end{array}$ & 1992 & $\begin{array}{l}\text { Guadalaja- } \\
\text { ra, Mexico }\end{array}$ & $\begin{array}{l}\text { This sewer explosion caused by galvanic corrosion of a galvanized steel pipeline blocking with a } \\
\text { steel gasoline pipeline. This explosion killed } 215 \text { people, injured } 1500 \text { people, and damaged } 1600 \\
\text { buildings. }\end{array}$ \\
\hline EL AL Boeing 747 Crash & 1992 & $\begin{array}{l}\text { Amster- } \\
\text { dam, The } \\
\text { Nether- } \\
\text { lands }\end{array}$ & $\begin{array}{l}\text { The crash occurred due to the two right engines separated from the wing because of the fuse pins } \\
\text { that hold the strut to the wings were debilitated by corrosion pits and fatigues. This crash killed all } \\
\text { 4-people on board and more than } 50 \text { people on the ground. }\end{array}$ \\
\hline Sinking of the Erika & 1999 & $\begin{array}{l}\text { Brittany, } \\
\text { France }\end{array}$ & $\begin{array}{l}\text { The tanker broke in two while carrying } » 30000 \text { tons of heavy fuel oil due to corrosion in the main } \\
\text { deck coaming, the portside and starboard inert gas system risers. »19800 tons spilled and cause } \\
\text { severe economic consequences on the region. }\end{array}$ \\
\hline $\begin{array}{l}\text { Carlsbad Pipeline Explo- } \\
\text { sion }\end{array}$ & 2000 & $\begin{array}{l}\text { New Mexi- } \\
\text { co, USA }\end{array}$ & $\begin{array}{l}\text { El Paso Natural Gas exploded due to severe internal corrosion in a 30-inch natural gas pipeline. } \\
\text { This incidence killed } 12 \text { people and a 3-vehicle destroyed. }\end{array}$ \\
\hline Prudhoe Bay Oil Spill & 2006 & $\begin{array}{l}\text { Prudhoe } \\
\text { Bay, Alaska }\end{array}$ & $\begin{array}{l}\text { This massive oil spillage due to the failure of BP's field pipeline corrosion monitoring and leak } \\
\text { detection systems. »267,000 gallons of crude oil leaked from a corroded transit pipeline. }\end{array}$ \\
\hline $\begin{array}{l}\text { Rupture of a High-Pres- } \\
\text { sure Vessel }\end{array}$ & 2009 & $\begin{array}{l}\text { Illinois, } \\
\text { USA }\end{array}$ & $\begin{array}{l}\text { Stress Corrosion Cracking of the walls of a pressure vessel causes Nihon Dempa Kogyo (NDK) } \\
\text { Company explosion. This explosion killed 1-person and wounded several others. }\end{array}$ \\
\hline $\begin{array}{l}\text { Rupture of a Natural Gas } \\
\text { Transmission Pipeline }\end{array}$ & 2016 & $\begin{array}{l}\text { Pennsylva- } \\
\text { nia, USA }\end{array}$ & $\begin{array}{l}\text { A 30-inch diameter natural gas transmission pipeline ruptured due to corrosion along with two of } \\
\text { the circumferential welds. This incidence results 1-home destroyed, 3-homes partially damages, } \\
\text { and several homes evacuated. }\end{array}$ \\
\hline Ohio State Fair accident & 2017 & Ohio, USA & $\begin{array}{l}\text { A pendulum-type thrill ride failed during operation due to the rust (thickness of the ride beam's } \\
\text { wall reduced). The malfunction left 1-person dead and several others injured. }\end{array}$ \\
\hline
\end{tabular}

\section{Cost of Corrosion}

Corrosion is considered as one of the significant problems for most of the industrialized countries. Before designing any industry, the effect of corrosion on the equipment and its surrounding always deserve to be a considerable issue. The oil companies all over the world to mitigate this corrosion problem have expensed a lot of money. Nevertheless, disasters such as casualties, economic losses, and environmental side effects triggered by corrosion, still happen quite often [7]. Corrosion can cause severe failures in boiler tanks, pressure basins, blades of motors/turbines, harmful/aggressive chemical containers, airplane parts, automotive routing devices, and bridges.

Furthermore, the losses caused by corrosion are not only limited to metals but also extend to water, energy, and the manufacturing phase of the metal frames [8]. Jayaherdashti reported the typical maintenance cost of corrosion-related issues for a particular country varies from 1-5\% of its gross national product (GNP) [9]. NACE international conducted a global study on corrosion costs and preventative strategies in 2013, which was utilized in the World Bank economic sector and global Gross Domestic Product (GDP) data to relate the cost of corrosion. This study showed that the estimated global cost of corrosion was approximately $3.4 \%$ of the GDP (Figure 1a) [10]. To address the economic sectors across the world, World Bank divided the global economy into economic regions with similar economy categories and presented in Table 3 (Figures 1a \& 1b).

Table 3: Global cost (Billion US\$) ${ }^{\mathrm{a}}$ of corrosion by sectors and regions.

\begin{tabular}{|c|c|c|c|c|c|c|}
\hline \multirow{2}{*}{\begin{tabular}{c} 
Economic Regions \\
\cline { 2 - 8 }
\end{tabular}} & Agriculture & Industry & Services & Total & Total GDP & \% GDP \\
\hline United States & 2 & 303.2 & 146 & 451.3 & 16,270 & 2.7 \\
\hline India & 17.7 & 20.3 & 32.3 & 70.3 & 1,670 & 4.2 \\
\hline European Region & 3.5 & 401 & 297 & 701.5 & 18,331 & 3.8 \\
\hline Arab World & 13.3 & 34.2 & 92.6 & 140.1 & 2,789 & 5 \\
\hline China & 56.2 & 192.5 & 146.2 & 394.9 & 9,330 & 4.2 \\
\hline
\end{tabular}




\begin{tabular}{|c|c|c|c|c|c|c|}
\hline Russia & 5.4 & 37.2 & 41.9 & 84.5 & 2,113 & 4 \\
\hline Japan & 0.6 & 45.9 & 5.1 & 51.6 & 5,002 & 1 \\
\hline Four Asian Tigers Plus Macau & 1.5 & 29.9 & 27.3 & 58.6 & 2,302 & 2.5 \\
\hline Rest of the World & 52.4 & 382.5 & 117.6 & 552.5 & 16,057 & 3.4 \\
\hline Global & 152.7 & 1446.7 & 906 & 2505.4 & 74,314 & 3.4 \\
\hline
\end{tabular}
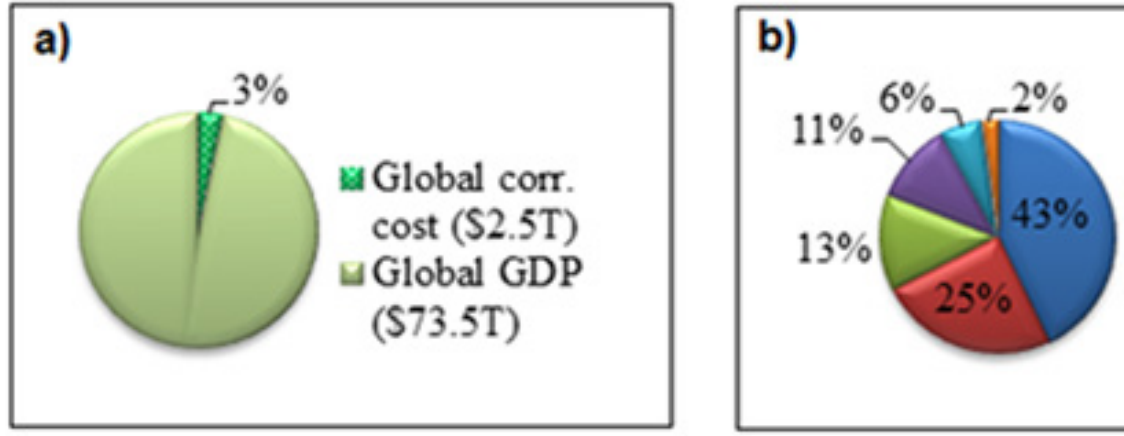

$\square \mathrm{KSA}(\$ 24.8 \mathrm{~B})$

G UAE (\$14.2B)

$\triangle \mathrm{Q} a \operatorname{tar}(\mathrm{S} 7.7 \mathrm{~B})$

$\square$ Kuwait (\$6.5B)

$\triangle O \operatorname{man}(\$ 3.3 \mathrm{~B})$

$\square$ Bahrain (\$1.2B)

Figure 1: a) Global cost of corrosion (2013), b) Cost of corrosion in GCC countries (2011).

Lim investigated the corrosion-related cost for the Gulf Cooperational Council (GCC) and presented in Figure 1b [11]. This study suggested that the Kingdom of Saudi Arabia (KSA) spent the highest to tackle the corrosion. Besides, the UK spent $£ 13.65 \mathrm{~B}$ to handle the corrosion-related issue in 1969 [12]. A 2-year study conducted by the USFHWA and NACE in 2002 disclosed that the estimated annual cost of corrosion in the country was US\$276 B, which was $3.1 \%$ of the US GDP. Nearly half of the amount was allotted for establishing corrosion mitigation methods, such as the selection of mechanically resistant plastics and corrosion-resistant alloys, development of protective coatings, corrosion inhibitors, and cathodic protectors [3]. Gas and oil production is one of the leading energy sectors, contributes a considerable portion of the direct costs for corrosion [13]. The total cost of oil and gas production and exploration is approximately US\$1.4 $\mathrm{B}$, while chemical/petrochemical manufacturing contributes US\$1.7 B, and petroleum refining adds US\$ $3.7 \mathrm{~B}$ [14].

\section{Mitigation of Corrosion}

Corrosion mitigation in a corrosive environment is a considerable challenge, and one of the most significant costs faced by industry across the world. NACE international commences a global study on corrosion costs and preventative strategies. The study showed that the USA E\&P sector, chemicals, and refining and downstream spent US\$1.4 B, US\$1.7 B, and US\$3.7 B per annum, respectively. Therefore, it is in time demand for exploring smart and corrosion mitigation techniques.

To increase the shelf life of the equipment and/or plant/ industry is still very challenging for industry personnel. There are several methods have been proposed for controlling corrosion. They can be categories with the classes as
- $\quad$ Choosing proper construction material for a particular application.

- Choosing proper or modifications of corrosive media.

- $\quad$ Producing a barrier between the metal and medium to circumvent the direct interaction.

To control the corrosion and to choose suitable corrosion mitigation techniques, the corrosion mechanism should be clearly understood. As a whole, the corrosion attack in a plant/industry can be minimized by applying the internal and external mitigation methods. The internal corrosion mechanism can be observed in aqueous corrosion systems, which caused by soluble corrosive gas, such as $\mathrm{CO}_{2}, \mathrm{H}_{2} \mathrm{~S}$, and $\mathrm{O}_{2}$. In addition to these mechanisms, microorganisms can also influence corrosion. To mitigate this type of corrosion, scavenging and biocide treatment can be used. Importantly, the use of corrosion inhibitor (10-1000 ppm continuously or $1-20 \%$ in a batch) could be the most essential and standard form to mitigate internal corrosion. The inhibitors usually affect the anodic and/or cathodic electrochemical reactions. They influence the corrosion process, therefore reduce the corrosion rate. Scavenger can be used to mitigate internal corrosion if the inhibitor could not reduce the corrosion rate. Considering the importance of a specific corrosive environment where corrosion failure can be caused by oxygen corrosion from seawater pipelines and fatigue failure from design and stress exerted onto the line or inexplicable mechanism, the external mitigation technique can be applied. In these settings, the coatings and cathodic protection are the best choices of external mitigation technique. The corrosive environment, which causes corrosion, can be segregated, providing a layer on the surface of the pipe. For cathodic protection, the metal needs to be converted to cathodic for another metal or anode. 
However, when considering the design of a cathodic protection system, the detailed methodological information and suitable standards are required to be considered.

\section{Conclusion}

This review article briefly discusses the basic concept of corrosion, followed by a discussion on the impact of corrosion, consequences, and cost of the corrosion. Moreover, different corrosion mitigation methods have also discussed briefly with an understanding of the corrosion mechanism, which is very important before considering various material options for applications.

\section{Acknowledgment}

The author gratefully acknowledges King Fahd University of Petroleum \& Minerals, Dhahran, Saudi Arabia, for supporting this research.

\section{Conflict of Interest}

The author declares no conflict of interest.

\section{References}

1. Mattson E (1989) Basic corrosion technology for scientists and engineers. Ellis Horwood Publishers, West Sussex, England.

2. Videla HA (1996) Manual of biocorrosion. CRC Press, London.

3. Tiu BDB, Advincula RC (2015) Polymeric corrosion inhibitors for the oil and gas industry: Design principles and mechanism. React Funct Polym 95: 25-45.
4. Nesic S (2007) Key issues related to modelling of internal corrosion of oil and gas pipelines. Corros Sci 49(12): 4308-4338.

5. Hamilton WA (1985) Sulphate-reducing Bacteria and Anaerobic Corrosion. Annu Rev Microbiol 39: 195-217.

6. Davis J (2000) Corrosion: Understanding the Basics. First ed, ASM International.

7. Aljeaban NA, Goni LKMO, Alharbi BG, Mazumder MAJ, Ali SA, et al. (2020) Int J Polym Sci 9512680: 1-23.

8. Raja PB, Ismail M, Ghoreishiamiri S, Mirza J, Ismail MC, Kakooei S, et al. (2016) Chem Eng Commun 203: 1145-1156.

9. Javaherdashti R (2000) Microbiologically influenced Corrosion. AntiCorrosion Methods Mater 47: 30-34.

10. Koch GH, Varney J, Thompson N, Moghissi O, Gould M, et al. (2012) International measures of prevention, application, and economics of corrosion technologies study. NACE International, Houston.

11. Lim HL (2012) Material Science and Engineering: Concepts, Methodologies, Tools and Applications. Int J Corros, pp. 1-10.

12. Baker H, Okamoto H (1992) ASM Handbook Volume 3: Alloy Phase Diagrams. ASM International, Ohio.

13. Finšgar M, Jackson J (2014) Application of corrosion inhibitors for steels in acidic media for the oil and gas industry: A review. Corros Sci 86: 1741.

14. Koch GH, Brongers MPH, Thompson NG, Virmani YP, Payer JH (2002) Corrosion costs and preventive strategies in the United States. NACE International, Houston. 